少量カルボプラチン・放射線併用療法の検討

仙波 治・瀬尾律・渡辺 雄介

\title{
Evaluation of Chemoradiotherapy of Low Dose Carboplatin (CBDCA) for Head and Neck Cancer
}

\author{
Osamu Semba, Takashi Seo and Yusuke Watanabe \\ (Osaka Koseinenkin Hospital)
}

\begin{abstract}
We investigated 29 evaluable cases who received concurrent chemotherapy with low dose carboplatin and radiotherapy among 99 cases diagnosed with head and neck cancer at our institute in the 2 years and 5 months prior to December 1993.

Approximately $90 \%$ had advanced cancer, and all cases involved squamous cell carcinoma (SCC) except for one case involving adenocarcinoma that metastasized from the lung.

Among 28 cases of SCC which could be assessed by TNM classification, 17 of 25 lesions (68\%) showed clinical or pathological $\mathrm{CR}$ as determined by tumor volume $(\mathrm{T})$.

CR occurred in one $T_{1}\left(100 \%\right.$ of evaluable cases), seven $T_{2}(70 \%)$, three $T_{3}(60 \%)$ and six $T_{4}$ $(67 \%)$ cases.

In consideration of the lymph nodes (N), 15 for 20 cases (75\%) showed $\mathrm{CR}$, including three $\mathrm{N}_{1}$ (100\%) and twelve $\mathrm{N}_{2}(100 \%)$ cases. Five $\mathrm{N}_{3}$ cases showed no response. From these results, we conclude that it is possible to expect a cure of the lesion and functional preservation, even in such advenced cancer using combined therapy alone, if case selection is carefully performed.
\end{abstract}

Key words : carboplatin (CBDCA), radiation, head and neck cancer

はじめに

頭頸部悪性腫瘍に対しては，手術療法，放射線療法， 化学療法などの集学的治療が必要であるが, 患者の QOL や手術拒否などにより，十分に治療が行えない場 合も少なくない。今回我々は, 放射線療法に少量カルボ プラチン(以下 CBDCA)の同時併用療法を行い，機能温 存の面からも現時点ではほぼ満足のいく結果が得られた ので報告する.

\section{症例および方法}

1991年 8 月より1993年12月までの 2 年 5 力月間に当科 を初診し, 入院加療を行った頭頸部悪性腫瘍患者99例の らち, シスプラチン(以下 CDDP) の誘導体である
CBDCA を，放射線照射と同時併用した症例は36例であ った. そのらち腫瘍再発例やこの療法を予定ど沶り行ら ことができなかった症例を除き，評価可能な 29 例につい て検討した。

症例は, 年齢 45 歳から85歳で, 男性 24 例, 女性 5 例で あった. 発生部位別では, 口腔 6 例, 上咽頭 4 例, 中咽 頭 6 例, 下咽頭 2 例, 喉頭 5 例, 鼻副鼻腔 4 例, 中耳特 よび肺各 1 例であった. 病期別ではIII期 3 例， III期 2 例, $\mathrm{N}$ 期23例で， III， $N$ 期を含めた進行癌症例は約 $90 \%$ であ った. 組織学的には, 肺癌の腺癌を除いてすべて扁平上 皮癌であった。

治療は原則として放射線治療, リニアック 1 回 $2 \mathrm{~Gy}$ を週 5 回照射し合計 40〜 $60 \mathrm{~Gy}$ とした. CBDCA は症例 
の年齢, 体重, 腎機能, 全身状態により, 1 回 20 50 $\mathrm{mg}$ を放射線照射日と同じ日に点滴静注を行った。 CBDCA 投与量は全身状態の変化や局所所見, 血小板数 などにより決定した．また腫瘍の巨大な症例には，ペプ ロマイシン(以下 PEP) $5 \mathrm{mg}$ を週 2 回投与した.PEP 投与例は 8 例 (27.6\%)であった（表 1$)$ ）放射線照射量が ほぼ 40 Gy に達した時点で効果を判定し, 手術療法を 行らか，追加照射するかを決定した。

表 1 少量カルボプラチン・放射線併用療法

\begin{tabular}{ll}
\hline \hline リニアック & 1 回照射量 \\
& 5 回/週 \\
& 合計照射量 $\quad 40 \mathrm{~Gy} . \sim 60 \mathrm{~Gy}$. \\
カルボプラチン & $20 \mathrm{mg} \sim 50 \mathrm{mg} / \mathrm{body}$ \\
$(\mathrm{CBDCA})$ & 5 回/週 $($ リンック照射と同日)点滴静注 \\
& 末梢血液像・血液生化学・尿検查 1 回/週
\end{tabular}

\section{結果}

発生部位別に症例を検討すると, 口腔では(表 2 ), 硬 口蓋, 舌, 口腔底が各 2 例であった. 症例 1 では初診時 すでに肝転移があり, 大きな膿瘍が存在した。 しかし原 発部位, 頸部リンパ節転移は $42 \mathrm{~Gy}$, CBDCA $450 \mathrm{mg}$ で有効 (以下 PR) となったが, 全身状態の悪化で治療が 続行できなかった. 症例 3 は, $40 \mathrm{~Gy}$, CBDCA $760 \mathrm{mg}$ で摘出術を行ったが, 組織学的に癌細胞の残存は認めな かった. 症例 4 は, $30 \mathrm{~Gy}$, CBDCA $640 \mathrm{mg}$ で舌半切除 術, 上頸部郭清術を行ったが組織学的に原発部位に癌細 胞は認めたが，頸部リンパ節に癌細胞は認めなかった。

しかし 7 力月後に再発し 1 年 4 力月後の現在担癌生存中 である. 症例 5 は, $40 \mathrm{~Gy}, \mathrm{CBDCA} 800 \mathrm{mg}$ で口腔底舌 半切除術, 上頸部郭清術を行ったが組織学的に原発部位 に癌細胞を認めるも, 頸部リンパ節には癌細胞は認めな かった. しかし 5 カ月後上深頸部リンパ節に再発を認め たが原発部位は制御されていた.

上咽頭（表 3 )では，すべて $\mathbb{N}$ 期，低分化型であったが， 2 例は制御できている。症例10は頭蓋底浸潤を認めたが， 経過良好である。

中咽頭 (表 4 )でもすべて $\mathrm{N}$ 期であったが，扁桃原発 4 例はすべて非担癌生存中である. 症例14は高齢で $\mathrm{M}_{1}$ 症 例なので, $45 \mathrm{~Gy}, \mathrm{CBDCA} 220 \mathrm{mg}, \mathrm{PEP} 10 \mathrm{mg}$ で原発 部位, 頸部リンパ節転移も著効 (以下 $\mathrm{CR}$ ) となった。し
かし退院後 MRSA 肺炎で死亡した。症例15は同時重複 癌で, 舌根部は PR となるも食道癌の方は制御できなか ったが，一時 3 カ月自宅療湌ができた.

下咽頭癌 2 例(表 5 ) 中, 症例 18 では原発部位は $60 \mathrm{~Gy}$, CBDCA 1,050 mg で喉頭保存できて拈り，頸部リンパ 節は治療後も約 $2 \mathrm{~cm}$ 余触知したため頸部郭清術のみ行 ったが，組織学的に癌細胞は認めなかった.

喉頭（表 6 )では，症例23を除いてすべて $\mathrm{N}$ 期で，症例 22を除いてすべて声門上部癌であった．症例22は頸部や 縦隔洞リンパ節転移に対してこの治療法を適応させたが， 原発部位执よび頸部リンパ節のみにしか効果がなく，縦 隔洞リンパ節転移で死亡した。声門上部癌症例 4 例はす べてこの治療法のみで制御されている.

鼻副鼻腔領域（表 7 ) は症例24を除いて制御されている。 症例24は高齢で頭蓋内浸潤もあったが，一時的に CR と なるも全身状態の悪化と MRSA 感染も加わり死亡した

耳の症例（表 7 ）は 1 例だけであるが，広範な頭蓋内， 脳実質内への浸潤を認めたが， $60 \mathrm{~Gy} ， \mathrm{CBDCA} 900 \mathrm{mg}$ ， PEP $55 \mathrm{mg}$ で腫瘍の縮小もみられ, 顔面神経麻痺も改 善したが不幸な転帰をとった。

肺の症例（表 7 ）も 1 例であるが，手術不能例で $60 \mathrm{~Gy}$ ， CBDCA $750 \mathrm{mg}$ でPR となり，4回の入退院を繰り返 しながらも，初診より 1 年 4 力月余社会生活や自宅療養 ができた。

次に TNM 分類可能な扁平上皮癌症例について, こ の治療法の T, Nに対する効果を検討した(表 8 )。 まず $\mathrm{T}$ に対して評価可能な 24 例，25部位について，照射量 30〜60 Gy, CBDCA 220〜1, $400 \mathrm{mg}$ と差はあるものの， 臨床的または組織学的に CR となったものは，25部位中 17部位 $(68 \%)$ で, CR 率は T1 1 部位 $(100 \%), \mathrm{T} 27$ 部 位 $(70 \%)$, T3 3 部位 $(60 \%), \mathrm{T} 46$ 部位(67\%)であっ た. 表 8 には各群の照射量と CBDCA 投与量の平均を 表わした． Nに対して評価可能な20例では， CR となっ た症例は15例(75\%)で，N1 3 例(100\%)，N2 12例(100 \%), N3 0 例 ( $0 \%)$ であった.

次に副作用では，照射単独例と比較してとくに顕著な 差は認めなかったが，血小板減少が法とんどの症例に認 められ，血小板が10万以下になった時点で CBDCA の 投与を中止した。 また腎機能，血小板以外の血液像，肝 機能，電解質にはほとんぞ影響はなかった。

次に代表例を供覧する。症例11は 1 週間前よりの血痰 を主訴として，平成 4 年 3 月 17 日初診した。図 1 は治療 


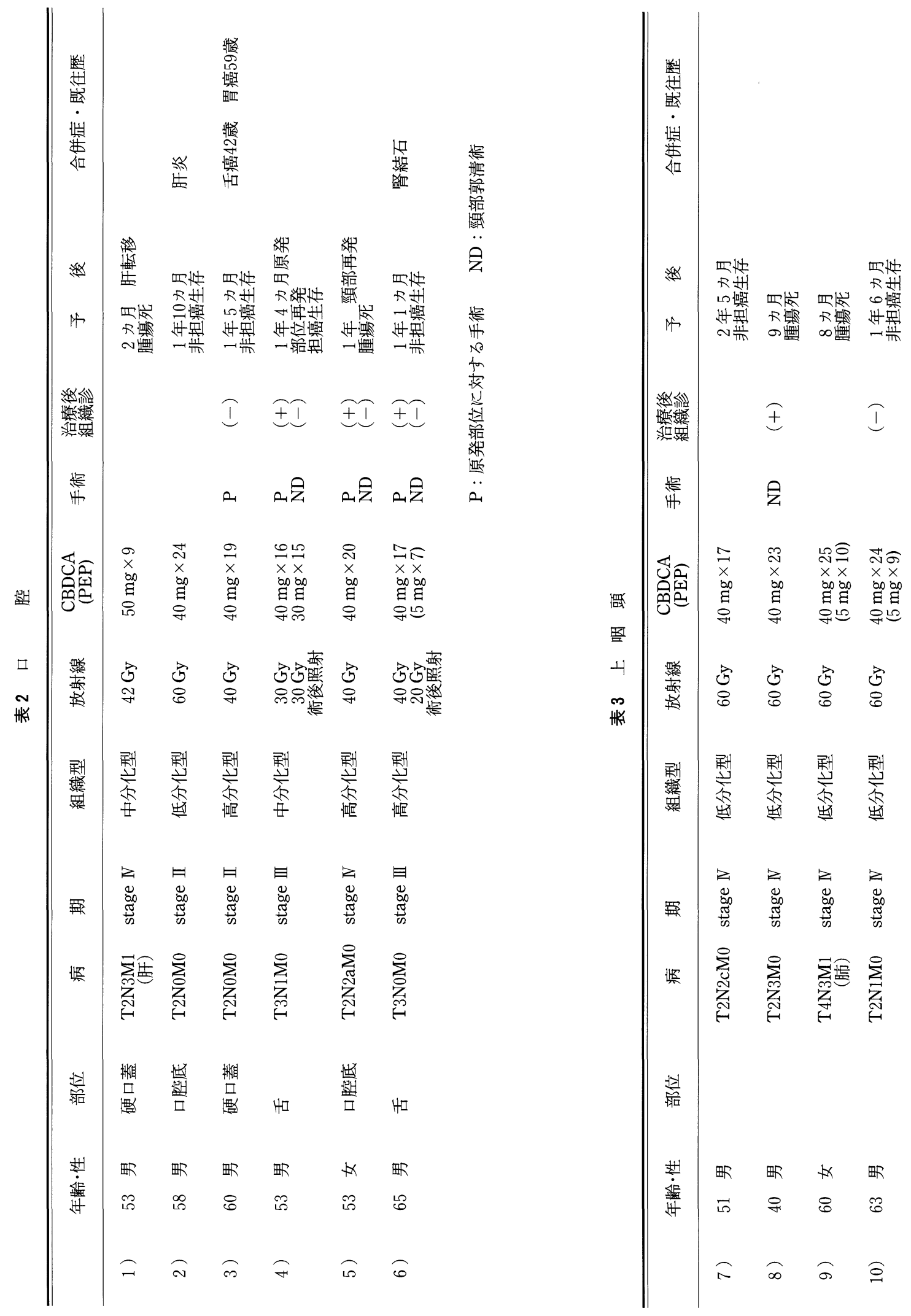



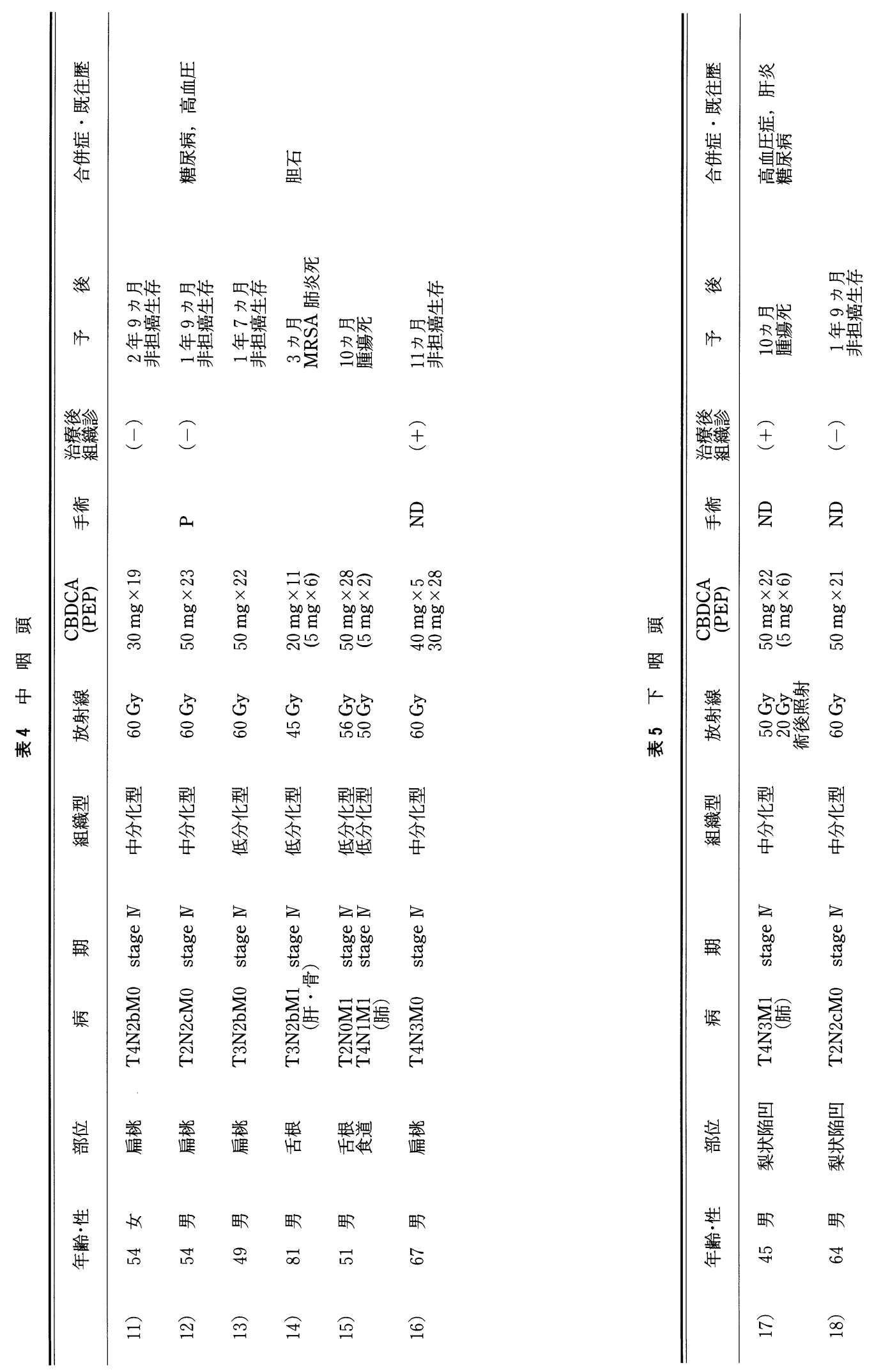


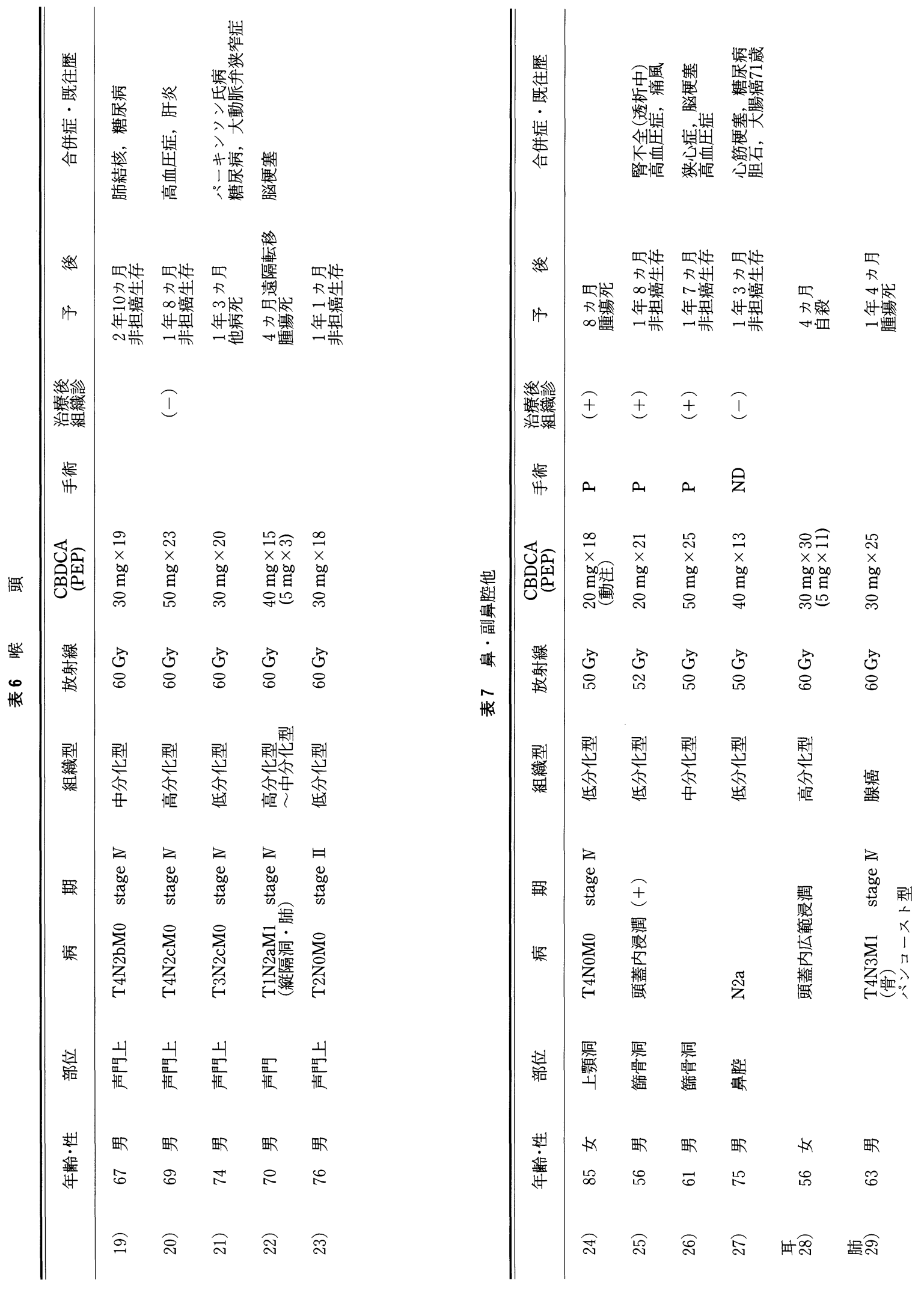


表 $8 \mathrm{~T} \cdot \mathrm{N}$ 亿対する $\mathrm{CR}$ 率

\begin{tabular}{|c|c|c|c|c|c|c|}
\hline $\mathrm{T}:$ & CR 例数 (CR 率) & $\begin{array}{l}\text { 平均 } \\
\text { 照射量 }\end{array}$ & $\begin{array}{l}\text { CBDCA } \\
\text { 平均投与量 }\end{array}$ & $\begin{array}{l}\text { 非 CR } \\
\text { 例 数 }\end{array}$ & $\begin{array}{l}\text { 平均 } \\
\text { 照射量 }\end{array}$ & $\begin{array}{l}\text { CBDCA } \\
\text { 平均投与量 }\end{array}$ \\
\hline $\mathrm{T}_{1}$ & $1(100 \%$ & $60 \mathrm{~Gy}$. & $600 \mathrm{mg})$ & 0 & & \\
\hline $\mathrm{T}_{2}$ & $7(70 \%$ & $57 \mathrm{~Gy}$. & $860 \mathrm{mg})$ & 3 & (46 Gy. & $900 \mathrm{mg})$ \\
\hline $\mathrm{T}_{3}$ & $3(60 \%$ & $55 \mathrm{~Gy}$. & $640 \mathrm{mg})$ & 2 & (35 Gy. & $660 \mathrm{mg})$ \\
\hline $\mathrm{T}_{4}$ & $6(67 \%$ & $58 \mathrm{~Gy}$. & $900 \mathrm{mg})$ & 3 & (53 Gy & $920 \mathrm{mg})$ \\
\hline & $17(72 \%$ & 7.5 Gy. & $770 \mathrm{mg})$ & 7 & $(52.6 \mathrm{~Gy}$ & $840 \mathrm{mg})$ \\
\hline
\end{tabular}

$\mathrm{N}$ :

\begin{tabular}{lrl}
$\mathrm{N}_{1}$ & $3(100 \%)$ & 0 \\
$\mathrm{~N}_{2}$ & $12(100 \%)$ & 0 \\
$\mathrm{~N}_{3}$ & $0(0 \%)$ & 5 \\
\hline & $15(75 \%)$ & 5
\end{tabular}

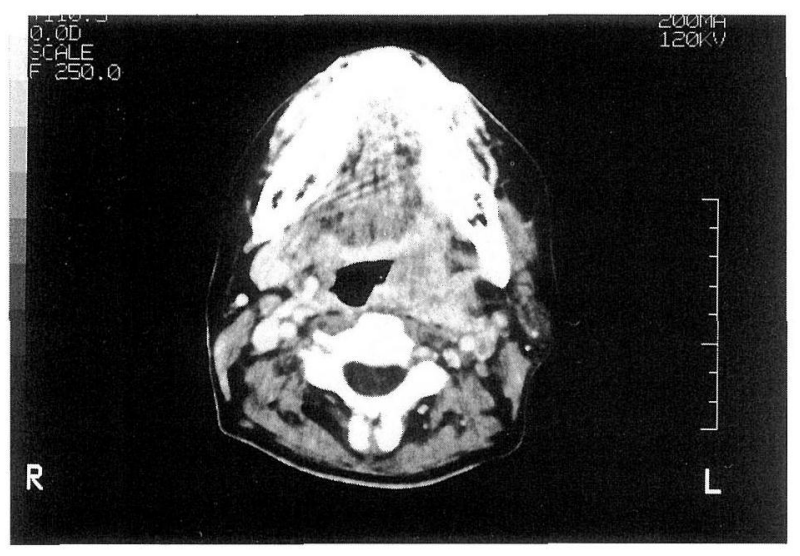

図 1 症例11の治療前

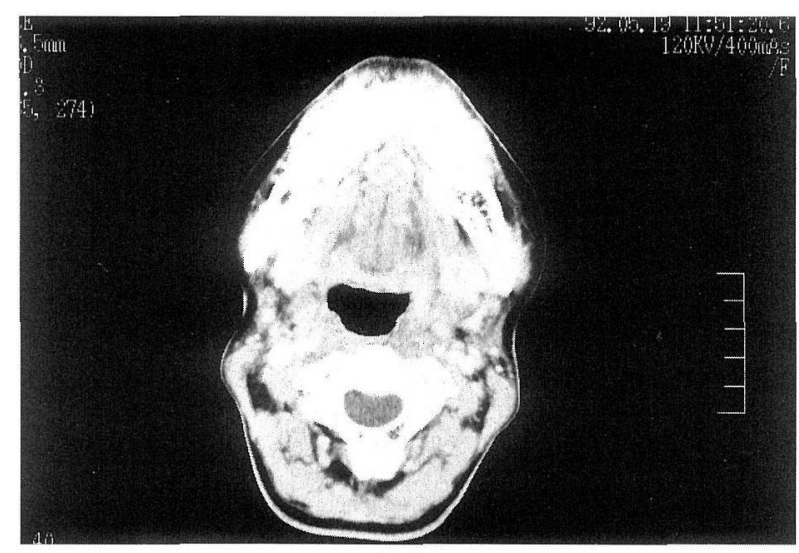

図 2 症例11の治療後

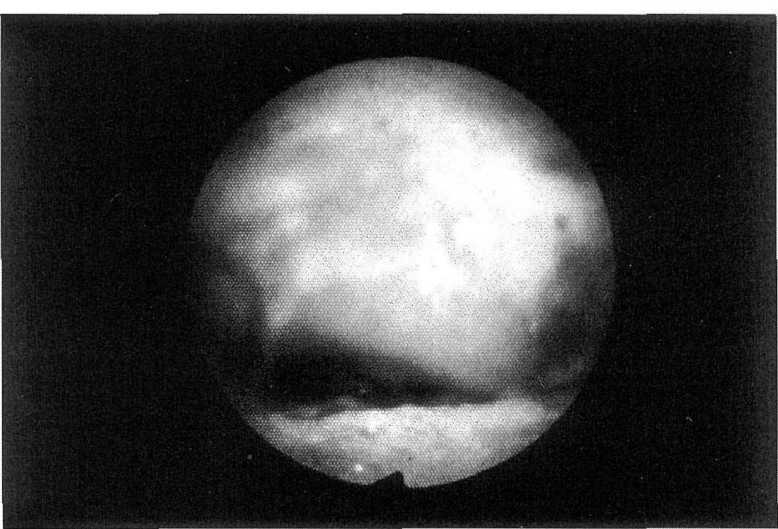

図 3 症例19の治療中

前の CT 像で，中咽頭左側壁から内側および副咽頭腔へ 広がる不整型の辺縁一部不明瞭な腫瘍を認める. 図 2 は 治療後の CT 像で, 中咽頭の左右差はなく, この時点で の咽頭よりの生検でも癌細胞の残存は認めなかった. 治 療後 2 年 9 力月の現在も再発, 転移は認めていない.

症例19は2 力月来の嗄声と咽頭痛が増強し, 器下困難, 呼吸困難感も出現したため，平成 4 年 1 月 17 日に当科を 初診. 初診時所見は, 喉頭蓋全体が腫瘍で腫脹し咽頭腔 の汷とんどを占めていた。図 3 はリニアック $14 \mathrm{~Gy}$, CBDCA $180 \mathrm{mg}$ 投与後で, 腫瘍のかなり縮小が認めら れ，喉頭蓋の先端が判定できるようになっている.40 Gy, CBDCA $570 \mathrm{mg}$ の時点で手術を予定していたが, 患者の強い手術拒否により照射を続行した。図 4 は治療 後のファイバースュープ所見で, 腫瘍は完全に消失し, 治療後 2 年10力月の現在も再発, 転移は認めていない. 


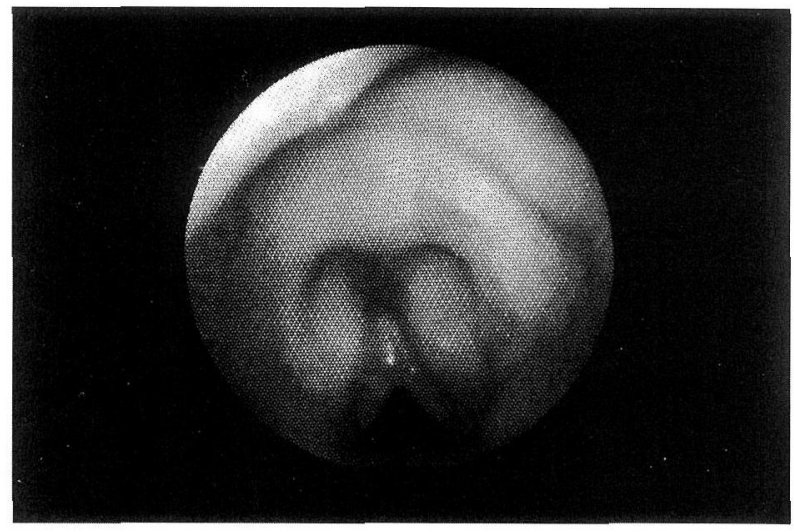

図 4 症例19の治療後

\section{考察}

頭頸部悪性腫瘍患者の QOL の立場より，可能な限り 機能保存を目的として, 放射線療法単独, あるいは化学 療法単独では自ずと限界があるために，これらの併用療 法が行われている。しかし両者の組久合わせ方や化学療 法剂の種類にも確たる方法は見出せていない，最近放射 線と CDDP あるいは，CDDP 誘導体である CBDCA と の併用療法が報告1)2)されてきている。我々はこれらの 報告をもと飞, CDDP と CBDCA の両者の以下にのべ る大きな作用上の差を考慮し，少量の CBDCA 放射線 同時併用療法を行った。CDDP と CBDCA の抗腫瘍効 果は同等と認められている ${ }^{3)}$ また CBDCA は，従来濃 度依存性薬剂といわれていたが，抗腫瘍効果は最高血中 濃度 $(\mathrm{Cmax})$ に依存するのではなく, 投与後の血中濃度 曲線下面積 (AUC : 血中濃度 $\times$ 時間) に依存することが 明らかになってきている4)。ゆ完にむやみに $\mathrm{Cmax}$ を上 げても, 副作用の面の及強調されて, 効果の面が評価さ れない可能性もある.

CBDCA は放射線増感作用があり，その作用は CDDP 飞比較して強いといわれている(5) 7)．とく飞腫瘍 内部にある細胞は, 低酸素, 低栄養で非分裂状態であり 放射線抵抗性である。年れらに対してもCBDCA は増 感作用を有する5)6)。また CBDCA は，DNA 飞対して鎖 内架橋を形成し，放射線照射で生じた DNA 鎖切断部の 修復を妨げると考兄られている8)。

次に体内動態の差として, CDDP と CBDCA の水和 反応の速度が異なり，CDDP は血漿蛋白と結合しやす く, 抗腫瘍活性をもつ蛋白非結合型白金(遊離型白金)濃
度の消失パターソは，佐々木ら9りによれは，CDDP は投 与 2 時間後には検出されないが，CBDCA では投与 8 時 間後でも総白金濃度の $85 \%$ 以上が抗腫瘍活性をもつ遊離 型白金であり, AUCの比は約 16:1 としている。また CBDCA は CDDP と同様に血漿中で蛋白と結合するが, その反応はゆっくりでかつ強固ではないために，遊離型 白金の半減期は CDDP よりはるかに長く, 逆に CBDCA は蛋白結合が少ないために，CDDP と比べ尿中に排泄 される率が高く，純白金の半減期は短い10)。气れゆ光に 副作用が少ないと考光られる。以上のことょり， CBDCA の連日少量投与法は，1 日当りの AUC は小さ いものの，5 日連続させるためにある程度の AUC が得 られ，乙か子副作用は AUC, $\operatorname{Cmax}$ が低く括さ克られ ているため発現頻度, 程度が低いのではないかと考光ら れた. 次に投与回数は，これらの薬剤の代謝をみると24 時間後には注湆血中に存在しないために，放射線増感作 用を目的とするならば，週 1 回よりは放射線照射日と一 致して投与する方がより効果的ではないかと考兄た。

CBDCA の耐性機構についての報告は現在みあたらな いが，CDDP の耐性機構は(1)生体内解毒機構の中心的 役割の細胞内グルタチオンンステムがあげられ，耐性獲 得細胞はグルタチオン濃度が上昇して招り，それが抗癌 鼡に対する感受性を低下させる。(2)細胞内の DNA 修復 機構の発達の 2 つがあげられる1112). CDDP (CBDCA) の投与方法之耐性獲得の関連についての報告はみられな い. CBDCA の連日少量投与を長期間行らと耐性獲得し やすいと考兄られがちであるが，抗腫痬効果を下をわる 投与量で長時間接触させると耐性出現があるが，抗腫瘍 効果のある濃度やAUC の場合は耐性獲得がないといわ れているが，現時点でははっきりしない，

今後の課題としては，口腔領域の舌，口腔底症例では 40 Gy しか照射しておららず，摘出標本の組織診はすべて 癌細胞が残存しているので，腫瘍の小さいものあるいは 放射線感受性のよい症例には，照射量を増やし機能保存 を考觉ている。そ他の口腔領域の結果には注ぼ満足し ている.

上咽頭, 中咽頭の結果には注涪満足でき, 下咽頭も $\mathrm{T} 2$ 症例にはこの治療法のみで機能保存できればと考兄 ている。㬋頭に対しては，声帯固定例には施行経験がな いので，声帯固定のない T2，T3，T4 の症例には積極的 にこの治療法を行いたい，T1 は従来ど招り放射線単独 で十分と考觉ている. 
鼻副鼻腔では, 50 Gy 照射後の組織診でもすべて癌細 胞陽性であるので，手術療法との併用が不可欠と考兄る.

Nに対する結果より，今後手術不能なリンパ節に対し ても減量手術を行いこの方法を施行しょうと考えている. 今後症例を重ね, 箃重な経過観察が必要と考えている.

$$
\text { まとめ }
$$

検討した29例の結果より, 経過が短く, 症例数も少な いが，以下のことが示唆された.

1. 原発部位に対しては, 症例, 照射量を考慮すれば, この治療法のみで以下の症例は十分制御でき, 機能保存 は可能である。

a) 舌, 口腔底: $\mathrm{T} 1, \mathrm{~T} 2$ の症例

b ）上咽頭, 扁桃：上咽頭 $\mathrm{T} 4$ を除く症例

c）下咽頭 : T1, T2 の梨状陥凹癌

d ）喉頭 : 声門癌 $\mathrm{T} 2$, 声門上癌の声帯固定のないも の

2. T3, T4 の舌, 口腔底, 鼻副鼻腔は手術療法を併 用する。

3. 頸部リンパ節転移に対しては， N1， N2 は制御可 能で, N3 は手術の併用が必要.

4. 今後も症例を重ね, 厳重な経過観察をしていく.

尚, 本論文の要旨の一部は, 第18回日本頭頸部腫瘍学会 (札 蜆)に执いて発表した。

\section{文 献}

1) 不破信和, 伊藤善之, 加藤恵利子, 他 : 放射線治療と化学 療法剤との併用に関寸る臨床研究. 癌の臨床 $39: 1710$ 1714, 1993.

2) Eisenberger M, Jacobs M, Sinibaldi V, et al; Simultaneous treatment with carboplatin and conventional radiation for patients with unresectable squamous cell carcinoma of the head and neck. Preliminary phase I and II results. Carboplatin (JM-8) Current Perspectives and Future Directions (ed by Yarbro JW). pp 195 201, WB Saunders, Philadelphia, 1990.

3) 犬山征夫, 戸川 清, 森田 守, 他 : 頭頸部癌に対する carboplatin の Phase II study. 癌と化療 $15: 2131 \sim 2138$, 1988.

4) 大津智子, 佐々木康綱 : 抗癌剂の pharmacodynamics. 癌 と化学療法 $20: 1741 \sim 1749,1993$.

5 ) Douple EB, Richmond RC, OHara JA, et al; Carboplatin as a potentiator of radiation therapy. Cancer Treatment Reviews 12 Suppl A : 111 124, 1985.

6 ) Douple EB and Richmond RC : Platinum complexes as radiosensitizers of hypoxic mammalian calls. Br J Cancer 37 Suppl III : 98 102, 1978.

7) Begg AC, Kolk J, Emondt J, et al ; Radiosensitization in vitro by cis-diammine (1,1-cyclobutanedicarboxylato) platinum (II) (carboplatin, JM8) and ethylenediamminemalonatoplatinum (II) (JM40). Radiother Oncol $9:$ 157 $165,1987$.

8) Vrana $\mathrm{O}$ and Brabec $\mathrm{V}$ : The effect of combined treatment with platinum complexes and ionizing radiation on DNA in vitro. Int J Radiat Biol 50 : 995 1007, 1986.

9 ) 佐々木康綱, 福田正明, 藤原康弘, 他 : Carboplatin 点滴 静注時の血中動態一Cisplatin との比較一. Chemotherapy $37: 280 \sim 284,1989$.

10）小島寛之, 大屋彰利, 高杉益充 : 新白金錯化合物カルボプ ラチンの体内動態. 化学療法の領域 $6: 2382 \sim 2389,1990$.

11）西谷 㹈, 善積 昇, 藤原 純, 他：白金錯体と癌細胞耐 性機序一Cisplatin 耐性卵巣癌細胞に上る検討一. 癌と化 学潦法 $15: 2871 \sim 2881,1988$.

12）小笠原勇人, 倉石安庸, 西篠長宏: 薬剂耐性, $\mathrm{b}, \mathrm{p}$ 糖蛋 白を介さない耐性. 癌化学療法1993〜 94(鶴尾隆, 他編). 113 121頁, 中外医学社, 東京, 1993.

$$
\left.\begin{array}{l}
\text { 原稿受付: 平成 } 6 \text { 年 } 11 \text { 月 } 28 \text { 日 } \\
\text { 原稿採択 : 平成 } 7 \text { 年 } 2 \text { 月 } 1 \text { 日 急載 } \\
\text { 別刷請求先 : 仙波 治 } \\
\text { † } 553 \text { 大阪市福島区福島 } 4 \text { 丁目 } 2-78 \\
\text { 大阪厚生年金病院耳鼻咽喉科 }
\end{array}\right)
$$

